\title{
A Reply: Imperfect Bargains, Imperfect Trials, and Innocent Defendants
}

\author{
Robert E. Scott $\uparrow$ and William J. Stuntz $\dagger_{\dagger}^{\dagger}$
}

To understand what is and is not wrong with plea bargaining, one must understand the relationship of bargains to trials. Unsurprisingly, we disagree with much of what Judge Frank Easterbrook and Professor Stephen Schulhofer say about that relationship. ${ }^{1}$ Most of those disagreements need not be rehearsed here; readers attentive enough to wade through their essays and ours will pick up the key points readily enough. But there is one point where the dispute is at once sharp and hidden. It has to do with the fact that both trials and bargains are flawed.

That fact might seem obvious, but the literature on this subject persistently manages to ignore it. And while there are many good insights in Easterbrook's and Schulhofer's comments, we think they both fall prey to the tendency to imagine perfection in one part of the system or the other. That tendency inevitably leads to one of two conclusions-plea bargaining is just fine the way it is, or it ought to be junked. These are, of course, the conclusions that Easterbrook and Schulhofer reach; indeed, they are the conclusions that nearly all scholarship on plea bargaining reaches. Notwithstanding their popularity, we think both polar positions are wrong.

Consider first the bargaining process. Easterbrook argues that bargains are better than trials-that plea bargaining efficiently allocates punishment even if (as he believes) the trial process is riddled with deception and governed by uninformed and sloppy decisionmaking. ${ }^{2}$ If Easterbrook is right, we should dispense with trials, and let prosecutors decide whom to send to jail and for how long. But bargains are not better than trials, for a reason common to all contracts: no system of consensual allocation is better than the dispute resolution process (legal and extralegal) that backs it up. If courts deciding contract disputes persistently (but randomly) got the parties' intentions wrong, the parties could not simply be trusted to solve the problem on their own, for they must contract in the shadow of the enforcement regime. So too here: prosecutors and

$\dagger$ Dean and Lewis F. Powell, Jr. Professor of Law, University of Virginia.

if E. James Kelly, Jr. Research Professor of Law, University of Virginia.

1. Frank H. Easterbrook, Plea Bargaining as Compromise, 101 YALE L.J. 1969 (1992); Stephen J. Schulhofer, Plea Bargaining as Disaster, 101 YALE L.J. 1979 (1992).

2. Easterbrook, supra note 1, at 1970-72. 
defendants bargain against the backdrop of the trial process that will decide their dispute if bargaining breaks down. If the trial process is flawed-if trials sometimes convict innocent defendants-bargaining will not fix the mistakes.

That much is hardly damning, but plea bargaining has deeper flaws. Prosecutors, like insurers, are charged with finding the occasional deserving claim in a sea of frauds. Claims granted too easily only encourage more frauds. And too readily accepting ${ }^{3}$ a defendant's claim of self-defense, or lack of intent, or mistaken identity-even when the claim has some ambiguous evidence to back it up 4 -only encourages copycat behavior by guilty defendants and their lawyers. ${ }^{5}$ Indeed, defense lawyers are in almost the same position: they must assume innocence claims by their clients are false unless proved, because such claims usually are false-criminal defendants, unlike clients in almost all other settings, have essentially nothing to lose by making false claims. This dynamic is not a problem in cases where bargaining takes place after investigation and evidence-gathering are complete, for then the parties can sift claims in precisely the manner that Easterbrook suggests. But bargaining usually happens earlier, often much earlier, when only the bare outline of the case is known to either side. ${ }^{6}$

Thus, prosecutors can be expected to make offers that fail to internalize relevant information that suggests defendants' innocence. Easterbrook, along with some segments of the economics literature on the subject, contends that this is no problem, since innocent defendants will then find it in their interest to go to trial. ${ }^{7}$ But that happy ending will materialize only if innocent defendants have the same risk preferences as guilty ones. If, as is more likely, innocent defendants as a class are significantly more risk averse than guilty defendants as a class, a prosecutor's failure to internalize a defendant's private information will cost the prosecutor nothing because the defendant, even if innocent, will take the deal anyway. This may not be earth-shattering, but neither is it a "barely perceptible theoretical ripple." Rather, the pooling problem we have identified goes to the core function of the process: its ability to separate the innocent from the guilty.

To be sure, this analysis assumes that innocent defendants risk conviction if their cases go to trial. If that assumption is wrong--if innocent defendants

3. "Accepting" the defendant's claim means not only taking it as truthful, but also taking it as possibly truthful, and hence deserving of some discount in the plea bargain.

4. The problem is not either-or; it applies to defendants whose claims of innocence are partially corroborated. See Robert E. Scott \& William J. Stuntz, Plea Eiargaining as Contract, 101 YALE L.J. 1909, 1936-37 (1992).

5. The idea that criminal false statements statutes deter such conduct, see Easterbrook, supra note 1, at 1971 , seems to us wildly implausible.

6. This is also our answer to Schulhofer's explanation, see Schulhofer, supra note 1, at 1982-83, of why the pooling phenomenon is nonexistent.

7. See Easterbrook, supra note 1, at 1969-70; see also Gene M. Grossman \& Michael L. Katz, Plea Bargaining and Social Welfare, 73 AM. ECON. REV. 749, 753-55 (1983).

8. The two commentators unite on this phrase. Easterbrook, supra note 1, at 1969; Schulhofer, supra note 1 , at 1981 . 
never lose at trial-plea bargaining is a perfect separation device because any rational innocent defendant will refuse all plea offers, go to trial, and win. ${ }^{9}$ Sadly, no one familiar with the process can accept this optimistic picture. Innocent defendants sometimes lose; the fact that the jury convicts means that guilt is very likely, but neither juries nor judges are perfect. Mistakes, tragic ones, happen.

This is where we part company with Schulhofer. He attacks our analysis because we want innocent defendants to be able to plead, if they so choose, under the best possible terms. In Schulhofer's view, they are better off going to trial, whether they think so or not. ${ }^{10}$ But he is right only if going to trial means winning at trial. For some it does. For others it means not just loss but disaster, given the substantially longer sentence that awaits a defendant who gambles on the trial process and loses. The choice is not between innocent defendants pleading guilty and the same defendants winning acquittals at trial-again, if trials are perfect, innocent defendants will not plead, and the problem disappears altogether. Rather, the choice is between permitting innocents to plead under the most favorable circumstances possible and forcing them to trial, where they risk vastly greater punishment.

Of course, any system that pushes innocent defendants to trial will thereby minimize the number of innocents who are convicted. But it will do so only at the cost of maximizing the amount of punishment each of those unfortunates receives. This result stands every known theory of distributional justice on its head. We would think it common ground that losses, especially unjust losses, are better spread than concentrated, all else being equal. Schulhofer, like most critics of plea bargaining, seems to prefer a few innocent defendants serving long prison terms to a larger number serving a few years apiece. ${ }^{11}$

Abolishing plea bargaining altogether might spread the loss a bit by forcing more (and more casual) trials. But the loss would still be more concentrated, and hence more substantial, than in the current regime. At least that is so unless, magically, a trial system that spends much less money per case (in order to accommodate many more cases) would do a better job than the current system of sifting the innocent from the guilty. Schulhofer hints at this possibility: he explicitly states that the error rate of scaled-down trials would be no worse, ${ }^{12}$ and argues that since prosecutors would screen cases better (which would occur only if trial error rates dropped), the overall effect would be

9. Grossman \& Katz, supra note 7, at 753-55, offer a formal proof of this proposition.

10. Of course, as we explain in our article, risk-averse innocent defendants will often plead guilty even when the terms are unfavorable. Scott \& Stuntz, supra note 4, at 1948. Thus, our goal is not to push them toward pleas rather than trials (as Schulhofer suggests), but to make the terms of their pleas marginally better.

11. Hence his insistent use of the number of convictions of innocent defendants as the relevant benchmark; he criticizes us for seeming to want more such convictions. Schulhofer, supra note 1, at 198387.

12. Id. at 2006. 
better. ${ }^{13}$ Our response is simple: if the system can both save money and increase accuracy in the trial process, it should do so, regardless of what choices are made about plea bargaining. But we should not compare apples and oranges. The only fair evaluation of plea bargaining is one that holds both resource $\mathrm{s}^{14}$ and decisionmakers' wisdom constant. If trials make mistakes now, a cheaper trial process would likely make more of them. The combination of a higher error rate and lower cost per trial would substantially reduce the cost to a prosecutor of getting a case wrong, just as it would raise the risk of losing clear cases. That adds up to a reduced incentive to separate the innocent from the guilty. Meanwhile, the gap between justice for the poor and the rich would widen because bad lawyers - the kind who represent poor defendants-would have a greater opportunity to injure their clients.

In short, we inhabit a world where bargaining is imperfect, trials are imperfect, and resources are limited. The hard but important task for legal doctrine is how to manage the necessary tradeoffs. While there are some important reforms that could substantially improve the picture-both Easterbrook and Schulhofer, for example, recommend better financing of defense counsel, a proposal we endorse-those reforms have long been obvious, if politically unattractive. Moreover, they tend not to have any particular bearing on plea bargaining: we would support better funding of defense counsel even if plea bargaining were abolished. The legal reforms that do bear on plea bargaining, changes that would make the system function more efficiently and would help reduce some of its biases against innocent defendants, are marginal. We think they are nevertheless useful. If habilual criminal laws were abolished, prosecutors' sentencing promises were enforced, and judges were encouraged to carefully scrutinize "above-market" plea agreements ${ }^{15}$ (the three changes we suggest in our article), defendants as a whole would be a little better off, and a disproportionate amount of the gain would go to innocents. There may be other, more far-reaching possibilities; our list was meant to be suggestive rather than exhaustive. But we believe the task of academics in this area is to get on with the business of finding them, and to abandon the all-or-nothing debate that has so preoccupied us all.

13. See id. at 2007-08.

14. It will not do to say, as Schulhofer does, that things would be better if we both abolished plea bargaining and spent more on the system as a whole. See id. at 2004-05. It would also function better if we kept plea bargaining and spent more on the system as a whole.

15. Both Easterbrook and Schulhofer state that this is currently the law. They are of course right that judges in virtually all jurisdictions are free to award sentences lower than those to which the parties have agreed. But we meant to suggest more than that. The current system in no way encourages judges to revise sentences downward, and our own anecdotal evidence suggests that revisions upward are much more common. We would institute a regime that called for close scrutiny of any plea agreement that involved a higher-than-normal sentence for the crime in question. Such a regime does not presently exist. 
One should not lose sight of the forest for the trees. Plea bargaining is, for the most part, efficient and fair. ${ }^{16}$ Though we raise an important problem in the bargaining dynamic, it is a problem that does not affect the mass of cases, and does not even affect all cases where the defendant is innocent. In most cases, we think the basic soundness of the bargaining regime is clear. And even in the cases that are affected by the pooling phenomenon, bargaining is probably better than the alternatives. The task for the system is thus a modest one: to better achieve the parties' desires at acceptable cost. This has long been the central task of contract law. Our goal is to suggest a marriage of the two. It seems to us long overdue.

16. Which is not to say that it conforms to the model of perfectly informed contracting, with the parties perfectly internalizing all costs and benefits. No contracts conform to that model. That is why we think Schulhofer's externalities argument is, while interesting, ultimately unavailing. See Schulhofer, supra note 1, at 1987-91. By the standards he applies to plea bargains, we think almost all civil settlements, and a good many run-of-the-mill deals, would fail. The goal in our article was to try to apply roughly the same standards to plea bargains that our system applies to other bargains. We continue to believe plea bargaining easily meets those standards. 
. 